\title{
Ice core evidence for a very tight link between North Atlantic and east Asian glacial climate
}

\author{
Urs Ruth, ${ }^{1}$ Matthias Bigler, ${ }^{2,3}$ Regine Röthlisberger, ${ }^{2,4}$ Marie-Louise Siggaard-Andersen, ${ }^{3}$ \\ Sepp Kipfstuhl, ${ }^{1}$ Kumiko Goto-Azuma, ${ }^{5}$ Margareta E. Hansson, ${ }^{6}$ Sigfus J. Johnsen, ${ }^{3}$ \\ Huayu $\mathrm{Lu}^{7}$ and Jørgen P. Steffensen ${ }^{3}$ \\ Received 14 August 2006; revised 28 October 2006; accepted 6 December 2006; published 9 February 2007.
}

[1] Corresponding millennial-scale climate changes have been reported from the North Atlantic region and from east Asia for the last glacial period on independent timescales only. To assess their degree of synchrony we suggest interpreting Greenland ice core dust parameters as proxies for the east Asian monsoon systems. This allows comparing North Atlantic and east Asian climate on the same timescale in high resolution ice core data without relative dating uncertainties. We find that during Dansgaard-Oeschger events North Atlantic region temperature and east Asian storminess were tightly coupled and changed synchronously within 5-10 years with no systematic lead or lag, thus providing instantaneous climatic feedback. The tight link between North Atlantic and east Asian glacial climate could have amplified changes in the northern polar cell to larger scales. We further find evidence for an early onset of a Younger Dryas-like event in continental Asia, which gives evidence for heterogeneous climate change within east Asia during the last deglaciation. Citation: Ruth, U., M. Bigler, R. Röthlisberger, M.-L. Siggaard-Andersen, S. Kipfstuhl, K. Goto-Azuma, M. E. Hansson, S. J. Johnsen, H. Lu, and J. P. Steffensen (2007), Ice core evidence for a very tight link between North Atlantic and east Asian glacial climate, Geophys. Res. Lett., 34, L03706, doi:10.1029/2006GL027876.

\section{Introduction}

[2] The most active players in Earth's climate system include the North Atlantic Ocean and the Asian Monsoon systems. The North Atlantic deep water formation drives the meridional overturning and thus influences strongly the atmospheric circulation in the North Atlantic region and the global ocean conveyor [Broecker, 1994]. The Indian and Asian Monsoonal circulation probably is the most energetic regional atmospheric circulation pattern due to the enormous interhemispheric latent heat transfer during northern

\footnotetext{
${ }^{1}$ Alfred-Wegener-Institut für Polar- und Meeresforschung, Bremerhaven, Germany.

${ }^{2}$ Climate and Environmental Physics, University of Bern, Bern, Switzerland.

${ }^{3}$ Now at Ice and Climate Research, Niels Bohr Institute, University of Copenhagen, Copenhagen, Denmark.

${ }^{4}$ Now at British Antarctic Survey, Natural Environment Research Council, Cambridge, UK.

${ }^{5}$ National Institute of Polar Research, Tokyo, Japan.

${ }^{6}$ Department of Physical Geography and Quaternary Geology, Stockholm University, Stockholm, Sweden.

${ }^{7}$ School of Geographical and Oceanographical Sciences, Nanjing University, Nanjing, China.
}

Copyright 2007 by the American Geophysical Union. 0094-8276/07/2006GL027876\$05.00 summer [Clemens and Oglesby, 1992]. Rapid climate changes exhibiting corresponding patterns have been reported from the North Atlantic region and from east Asia for the last glacial period and climatic teleconnections between these important systems seem likely on millennial time scales [Chen et al., 1997; Porter, 2001; Porter and An, 1995; Wang et al., 2005; Wang et al., 2001]. But the mechanisms are not well understood [Porter and An, 1995; Wang et al., 2005; Wang et al., 2001], and the question of synchrony has yet remained unanswered at high temporal precision because all records have their own and independent time scales. Exact knowledge of the relative phasing of these changes in the respective regions is highly desirable to better constrain the triggering, mediating and evolving processes. Here we show that the Greenlandic NGRIP [North Greenland Ice Core Project (NGRIP) members, 2004] ice core holds proxies - concentration and elemental composition of dust - to infer storminess and moisture transport in its east Asian source areas, respectively. This allows us for the first time to investigate North Atlantic and east Asian climate on the same time scale, i.e. without any relative dating uncertainties. We investigate rapid climate changes over the last $100 \mathrm{ka}$ using detailed high resolution ice core data of dust and water stable isotope ratios. The mineral dust aerosol has a soluble fraction (mainly calcium carbonate $\mathrm{CaCO}_{3}$ ) and a water-insoluble fraction (particles). Here, we use the term "dust" also to denote the insoluble fraction.

\section{Ice Core Dust and Asian Monsoon Climate}

[3] It is well established that the mineral dust found in central Greenland ice cores originates from east Asian deserts at present and also during the last glacial period [Biscaye et al., 1997; Bory et al., 2003, 2002; Svensson et al., 2000]. The dust is mobilized by strong surface winds, uplifted and entrained into long-range transport in the westerly jets [Sun et al., 2001] (see Figure S1 of the auxiliary material ${ }^{1}$ ). The Greenland ice core dust record (Figure 1a, see auxiliary material for methods) shows great variability during the last glacial age with very pronounced Dansgaard-Oeschger (DO)-events in strict anti-correlation with temperature $\left(\mathrm{r}=-0.94\right.$ for $\log (d u s t)$ vs. $\delta^{18} \mathrm{O}$ of centennial means), which is consistent with earlier Greenland results [Fuhrer et al., 1999; Mayewski et al., 1994; Ruth et al., 2003; Steffensen, 1997] and reflects a persistent coupling on orbital and millennial time-scales. The enor-

\footnotetext{
${ }^{1}$ Auxiliary material data sets are available at $\mathrm{ftp}: / / \mathrm{ftp}$. agu.org/apend/g1/ 2006gl027876. Other auxiliary material files are in the HTML.
} 


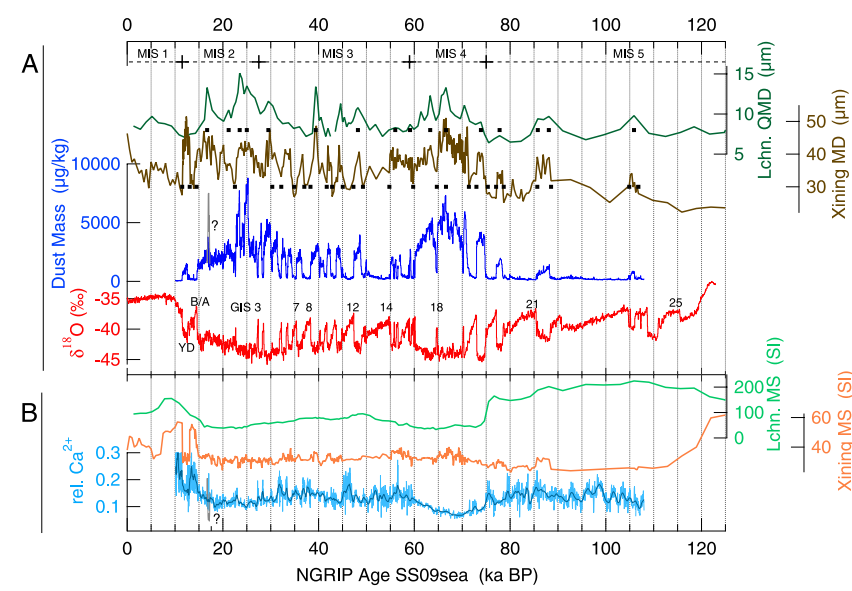

Figure 1. Time series of ice core and synchronized loess data both on the NGRIP SS09sea age scale [North Greenland Ice Core Project (NGRIP) members, 2004]. (a) Ice core $\delta^{18} \mathrm{O}$ [NGRIP members, 2004] and dust (insoluble particles) mass concentration together with loess grain size records for Luochuan (Lchn.) quartz mean diameter (QMD) and Xining mean diameter (MD). Black squares in the loess graphs mark the tie-points used for the age synchronization of the loess grain size records with NGRIP dust concentration. There is no control on the relative timing between the ice core and loess records for ages younger than $11.7 \mathrm{ka} \mathrm{BP}$ and older than $108 \mathrm{ka}$ BP. MIS is Marine Isotope Stage, YD is Younger Dryas, B/A is Bolling/Allerod, and GIS is Greenland Interstadial. The dust calibration is uncertain for the peak marked with a question mark at $17.0 \mathrm{ka}$ (see auxiliary material). (b) NGRIP ratio (rel. $\mathrm{Ca}$ ) of soluble $\mathrm{Ca}$ to insoluble dust together with loess magnetic susceptibility (MS) for Luochuan (Lchn.) and Xining. The loess data in Figures $1 \mathrm{a}$ and $1 \mathrm{~b}$ are from Lu et al. [2004] and Xiao et al. [1999]. The dark line for rel. $\mathrm{Ca}$ is the data after low pass filtering using a gliding window of 25 points or $\sim 900 \mathrm{yr}$. width.

mous increase of ice core dust concentrations must largely be attributed to increased dust storm activity in the source areas, which is consistent with findings for modern Greenland dust [Meeker and Mayewski, 2002], as the concentration changes due to changes in transport efficiency have been found limited in order to be compatible with the observed change of ice core dust particle size [Ruth et al., 2003].

[4] Dust storms not only lead to intercontinental transport of dust, but also form regional loess deposits within China, which are excellent archives of east Asian monsoon and dust storm activity [Porter, 2001; Sun et al., 2001]. In particular, the mean grain size (Mean Diameter, MD, or Quartz Mean Diameter, QMD) is taken as a proxy for the virulence of the mobilizing and transporting winds [Liu and Ding, 1998]. If the Greenland ice core dust concentration should indeed be a good proxy for east Asian dust storm activity then a close correspondence between the ice core dust and Chinese loess deposits should be expected. In Figure 1a we compare NGRIP dust data with two Chinese loess records: the well-studied profile from Luochuan [Xiao et al., 1999] $\left(35^{\circ} 35^{\prime} \mathrm{N}, 109^{\circ} 25^{\prime} \mathrm{E}\right.$; accumulation $\sim 10 \mathrm{~m} /$ $100 \mathrm{ka})$ in the central Chinese Loess Plateau and the high resolution profile from Xining [Lu et al., 2004] $\left(36^{\circ} 20^{\prime} \mathrm{N}\right.$, $101^{\circ} 40^{\prime} \mathrm{E}$; accumulation $\sim 40 \mathrm{~m} / 100 \mathrm{ka}$ ) on the north-eastern Tibetan Plateau. Given the meteorological setting and the close correspondences between the NGRIP dust and the Chinese loess data we have synchronized the loess records to the ice core timescale (see auxiliary material). Thus it must be noted that the synchrony of Greenland dust and Chinese loess in Figure 1a is a product of the age adjustment for the loess. But they clearly show a good correspondence in the DO events also by relative peak heights. This suggests that variations seen in the ice core record indeed represent climatic changes in China, even though they are not always visible in the loess due to its comparatively low time resolution or post-depositional modifications. We therefore suggest that NGRIP dust concentration can be used as a qualitative proxy for dust storm activity in east Asia.

[5] Until now insoluble dust and $\mathrm{Ca}^{2+}$ ion concentrations have been used as equivalent proxies for changes in the dust cycle [Fuhrer et al., 1999; Mayewski et al., 1994] and only little was known about the ratio of $\mathrm{Ca}^{2+}$ to insoluble dust [Ruth et al., 2002; Steffensen, 1997]. Figure 1b shows a continuous profile of the measured $\mathrm{Ca}^{2+}$ concentration divided by the insoluble dust mass (hereinafter called "rel. Ca") for the last glacial period. While $\mathrm{Ca}^{2+}$ and dust mass look indistinguishable by eye (not shown), it is striking that the profile of rel. $\mathrm{Ca}$ resembles neither the dust nor the $\mathrm{Ca}$ concentration profiles. The mean rel. nss-Ca is 0.13 , and there is only little variability given the large range of respective concentrations. The two main features are a strong increase of rel. Ca to approx. 0.25 starting at approx. $14.7 \mathrm{ka}$ BP and a persistent suppression of rel. Ca to approx. 0.07 during MIS 4.

[6] Rel. Ca in Greenland ice cores is not straight-forward to interpret. The $\mathrm{Ca}^{2+}$ derives predominantly from mineral calcium carbonate $\mathrm{CaCO}_{3}$ [Biscaye et al., 1997], the formation of which in Chinese semiarid areas is controlled essentially by wet-dry cycles and therefore is associated with precipitation [Liu and Ding, 1998]. Since mineralogic and isotopic studies indicate only slight variations of source location for Greenland ice core dust [Svensson et al., 2000] the simplest explanation for variable rel. $\mathrm{Ca}$ is a temporally varying composition of the source due to modifications of moisture advection.

[7] In Figure $1 \mathrm{~b}$ the NGRIP rel. Ca is shown along with magnetic susceptibility (MS) from Xining and Luochuan. MS becomes enhanced by minerals produced during soil formation, which is limited by water availability. Thus, throughout the loess literature MS is taken as a precipitation proxy for summer monsoon strength [Liu and Ding, 1998]. The two MS records are influenced differently by the Tibetan Plateau Summer Monsoon (Xining) and east Asian Summer Monsoon (Luochuan) [Lu et al., 2004; Xiao et al., 1999], and NGRIP rel. Ca shows aspects of both monsoonal systems. We limit our interpretation of NGRP rel. Ca to the last glacial termination (10ka to $20 \mathrm{ka} \mathrm{BP}$ ), where the signals are strong and correlate strongly and highly significant with Xining MS ( $r=0.88, p=10^{-16}$ for 200a means). From the likely causality and from the high observed correlation we suggest that smoothed values of "rel. Ca" in the NGRIP ice core may serve as a proxy for moisture advection in the 

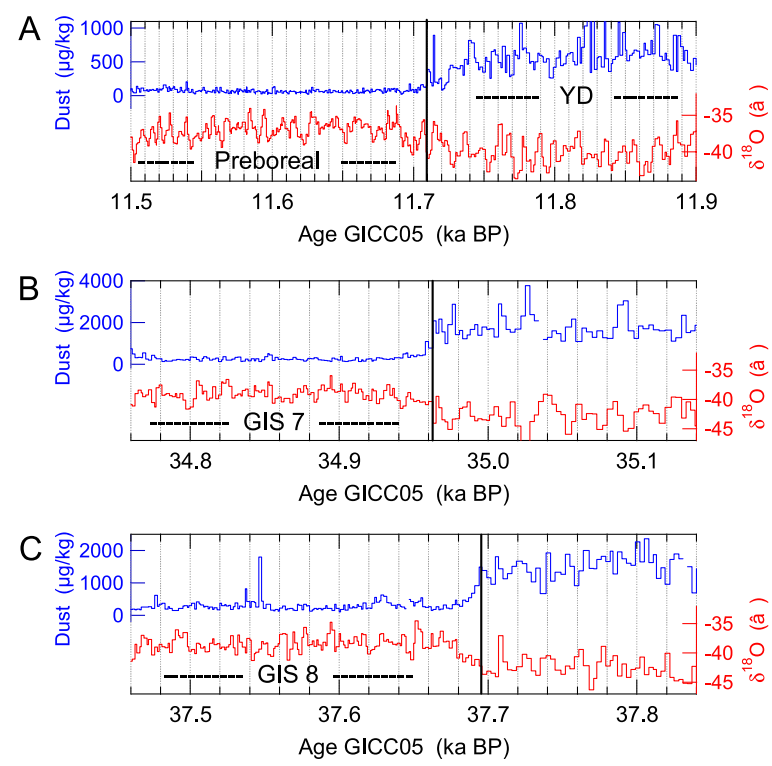

Figure 2. High-resolution ice core data during selected rapid warming transitions on the NGRIP GICC05 age scale [Andersen et al., 2006]. $\delta^{18} \mathrm{O}$ and insoluble dust mass concentration are shown for each example. (a) YDPreboreal transition, (b) inception of GIS 7, and (c) inception of GIS 8. Vertical lines mark the first irreversed and sustained decrease of dust, which is found coincident with an equivalent increase of $\delta^{18} \mathrm{O}$.

Asian source areas at least during this period of unusually powerful monsoon activity (see auxiliary material).

[8] These ice core proxies for east Asian climate change (dust concentration for dust storm activity and rel. Ca for

Figure 3. Details of NGRIP ice core data $\left(\delta^{18} \mathrm{O}\right.$, insoluble dust mass and rel. Ca) together with synchronized Xining loess data [Lu et al., 2004] (MD, mean diameter; MS, magnetic susceptibility) during the last glacial termination on the NGRIP GICC05 age scale [Rasmussen et al., 2006]. Black squares in Xining MD mark the tie-points used for the age synchronization of Xining MD to NGRIP dust concentration. Vertical line $\alpha$ marks the onset of the $\mathrm{B} / \mathrm{A}$ (1604.64 $\mathrm{m}, 14.723 \pm 156 \mathrm{a} \mathrm{BP})$, and $\delta$ marks the end of YD (1492.45 m, 11,734 \pm 69 a BP). The B/A-YD transition normally is placed at $\gamma(1526.52 \mathrm{~m}, 12,927 \pm 109$ a BP $)$ (depths and ages for $\alpha, \delta$ and $\gamma$ are adopted from [Rasmussen et al., 2006] and have there been defined as point of first change of deuterium excess); however, Xining MS and NGRIP $\mathrm{CaCO}_{3}$ abruptly change to YD-levels already at $\beta$ (1539.45 m, 13,200 \pm 119 a BP), some $270 \pm$ 50 years earlier. The assignment of the YD between $\gamma$ and $\delta$ is consistent with central European pollen data as is shown by the pollen ratio of tree vs. herbs from Meerfelder Maar [Litt et al., 2001], Germany; note that the pollen series has its own and independent chronology (counted varves). Also shown are atmospheric methane $\left(\mathrm{CH}_{4}\right)$ concentrations [Flückiger et al., 2004] from GRIP on the GICC05 time scale as well as isotopic composition of the H82 stalagmite from Hulu Cave [Wang et al., 2001] on its own time scale. YD is Younger Dryas, B/A is Bolling/Allerod; selected stratigraphic names according to INTIMATE [Björck et al., 1998] are also given. changes of moisture transport) are important tools as they offer excellent time control and very high temporal resolution. It is possible to compare them with $\delta^{18} \mathrm{O}$ (a proxy for North Atlantic region temperature) from the same ice core to investigate phase lags between these two regions at times of rapid climate change without any relative dating uncertainties. In the following we will look at case studies of DO events and at the Younger Dryas (YD).

\section{Dansgaard/Oeschger Events}

[9] To investigate timing patterns at rapid DO-onsets we now compare high resolution ice core data of dust concentration and of $\delta^{18} \mathrm{O}$. Figure 2 shows these data for three examples: Figure 2a shows the demise of the YD, Figure $2 b$ shows the inception of GIS 7, and Figure 2c shows the inception of GIS 8 . We define the point of the transition as the first irreversed step-like parameter change. The thus defined time for the decrease of dust concentration (marked by a vertical line in each panel) is coincident within approx. 5-10 years (one or two data points) with the equivalent increase of $\delta^{18} \mathrm{O}$ to warmer temperatures. For all DO inceptions in the record (GIS 1-24) the average lag of dust vs. $\delta^{18} \mathrm{O}$ is $1 \pm 8$ years, which indicates synchrony of dust concentration changes and $\delta^{18} \mathrm{O}$ changes. This suggests a strong coupling between east Asian dust storm occurrence

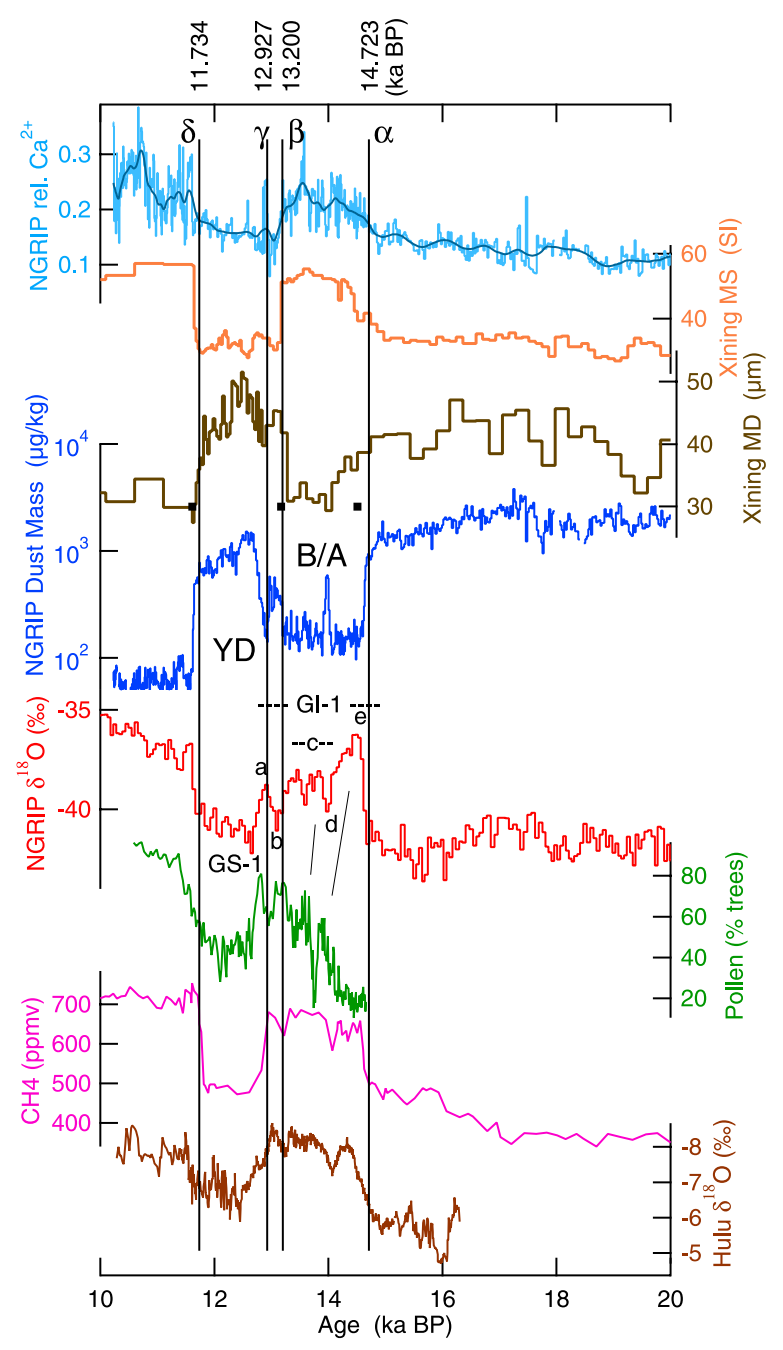


and North Atlantic region temperature even on time-scales of several years. This was a stable relationship over the entire last glacial period. We further find that the apparent time lag at any given DO inception does not depend on the magnitude of the temperature change, and we thus interpret that the apparent lead or lag at any individual inception may be the result from inherent variability in the data. Therefore, we propose that North Atlantic and east Asian climates may indeed have changed synchronously to the year at every DO inception during the last glacial period.

\section{Last Deglaciation}

[10] We will now look at the last deglaciation, which was disrupted by the YD cold event, a return to near-glacial conditions, found in ice-cores, marine and terrestrial records. Figure 3 shows in detail the NGRIP dust and Xining loess profiles on the new NGRIP GICC05 time scale. For the Bölling/Alleröd (B/A) warm period low NGRIP dust concentrations and small Xining grain sizes indicate that east Asian storminess was significantly reduced while high Xining MS and NGRIP rel. Ca indicate increased moisture transport into semiarid areas. Contrary to Nakagawa et al. [2003], our data show a synchronous onset of a pronounced $\mathrm{B} / \mathrm{A}$ period in Asia and in the North Atlantic region ( $\alpha$ in Figure 3). Our data further show that during the YD-excursion the North Atlantic temperature and Asian Summer Monsoon were in-phase correlated (as normal) and oppose the observation [An et al., 1993] of an exceptional anti-phase correlation during that period. North Atlantic and east Asian climate also change in synchrony at the termination $(\delta)$ of the YD. But at the B/A-YD transition there is a timing difference: The YD is commonly regarded to start at the transition (' $\gamma$ ') marked by the last and largest decrease in $\delta^{18} \mathrm{O}$ [Dansgaard et al., 1989; Rasmussen et al., 2006]. This practice is consistent with the reduction of global methane concentrations [Flückiger et al., 2004] and also with central European pollen archives [Litt et al., 2001], the type of archive from which the YD had originally been defined (Figure 3). However, NGRIP rel. Ca and independently also Xining MS already change to YD-levels at the onset of GI-1b ( $\beta$ in Figure 3), i.e. already $\sim 270 \pm$ 50 years earlier.

[11] This suggests that the weakening of the relevant branches of the summer monsoon precede the onset of the YD in certain parts of east Asia and that the monsoon did not fully recover during GIla. This timing difference is not only visible in the loess data but also in the ice core data and therefore is fully independent from the age-adjustment of the loess. Interestingly, the timing of the Hulu Cave record [Wang et al., 2001] corresponds to NGRIP $\delta^{18} \mathrm{O}$, thus indicating regionally non-coherent changes within the Asian Summer Monsoon systems. Such a timing difference of rel. $\mathrm{Ca}$ vs. $\delta^{18} \mathrm{O}$ has not been found for the other DO events, which suggests that climatic feedbacks may have been distinct during the last deglaciation, a time when the Asian Summer Monsoon was unusually powerful.

\section{Conclusions}

[12] Irrespective the regional timing difference during the deglaciation, our high-resolution ice core data show that during the last glacial period abrupt climate transitions in Eastern Asia were just as rapid and extensive as in the North Atlantic region; they do not support suggestions [Chen et al., 1997] from loess archives that climate variations were smaller on the Chinese Loess Plateau. The data show a high degree of temporal coherence of the east Asian monsoon system (represented by ice core dust concentrations) with North Atlantic climate (represented by ice core $\delta^{18} \mathrm{O}$ ) even at rapid climate changes, and we conclude that these regions were tightly coupled by persistent atmospheric processes over the last glacial period. Increased North Atlantic region temperature, triggered possibly by enhanced meridional overturning of the Atlantic and a shrinking atmospheric polar cell, instantaneously weakened east Asian Winter Monsoon and strengthened the Asian Summer Monsoon. Possible mechanisms include the impact of the Arctic Oscillation on the position and strength of the Siberian High [Gong et al., 2001] as well as the influence of North Atlantic SST on the Indian Summer Monsoon via controlling the meridional gradient of tropospheric temperature over Eurasia [Goswami et al., 2006]. Another mechanism may be the extent of Eurasian snow cover, which is negatively correlated to the strength of the subsequent summer monsoon because the strong differential heating between land and sea in east Asia is suppressed by a snow cover in sensitive areas, such as the Tibetan Plateau [Barnett et al., 1988]. These mechanisms likely persisted or were even reinforced during the last glacial period. A strengthened Summer Monsoon, on the other hand, leads to enhanced trans-equatorial south-to-north transport of latent heat [Clemens and Oglesby, 1992] thus extending the oceanic bi-polar see-saw [Blunier and Brook, 2001] by a very powerful atmospheric branch. The tight link between North-Atlantic and east Asian glacial climate potentially could have amplified changes in the northern polar cell to climate events of global extent and thus could have contributed significantly to the abruptness and extent of climate change during the last glacial period.

[13] Acknowledgments. NGRIP is directed and organized by the Department of Geophysics at the Niels Bohr Institute for Astronomy, Physics and Geophysics, University of Copenhagen. It is supported by funding agencies in Denmark (SNF), Belgium (FNRS-CFB), France (IPEV and INSU/CNRS), Germany (AWI), Iceland (RannIs), Japan (MEXT), Sweden (SPRS), Switzerland (SNF), and the USA (NSF, Office of Polar Programs). The loess investigation at Xining was supported by NSSF of China. Data are available from Pangaea at http://dx.doi.org/10.1594/ PANGAEA.587836.

\section{References}

An, Z., S. C. Porter, Z. Weijian, L. Yanchou, D. J. Donahue, M. J. Head, W. Xihuo, R. Jianzhang, and Z. Hongbo (1993), Episode of strengthened summer monsoon climate of Younger Dryas age on the Loess Plateau of central China, Quat. Res., 39, 45-54.

Andersen, K. K., et al. (2006), The Greenland ice core chronology 2005, 15-42 ka. part 1: Constructing the time scale, Quat. Sci. Rev., doi:10.1016/j.quascirev.2006.08.002, in press.

Barnett, T. P., L. Dümenil, U. Schlese, and E. Roeckner (1988), The effect of Eurasian snow cover on global climate, Science, 239, 504-507.

Biscaye, P. E., F. E. Grousset, M. Revel, S. Van der Gaast, G. A. Zielinski, A. Vaars, and G. Kukla (1997), Asian provenance of glacial dust (stage 2) in the Greenland Ice Sheet Project 2 ice core, Summit, Greenland, J. Geophys. Res., 102(C12), 26,765-26,781.

Björck, S., M. J. Walker, L. C. Cwynar, S. J. Johnsen, K.-L. Knudsen, J. J. Lowe, B. Wohlfarth, and INTIMATE members (1998), An event stratigraphy for the Last Termination in the North Atlantic region based on the Greenland ice-core record: A proposal by the INTIMATE group, J. Quat. Sci., 13(4), 283-292. 
Blunier, T., and E. J. Brook (2001), Timing of millenial-scale climate change in Antarctica and Greenland during the last glacial period, Science, 291, 739-743.

Bory, A. J.-M., P. E. Biscaye, A. Svensson, and F. E. Grousset (2002), Seasonal variability in the origin of recent atmospheric mineral dust at NorthGRIP, Greenland, Earth Planet. Sci. Lett., 196, 123-134.

Bory, A. J.-M., P. E. Biscaye, and F. E. Grousset (2003), Two distinct seasonal Asian source regions for mineral dust deposited in Greenland (NorthGRIP), Geophys. Res. Lett., 30(4), 1167, doi:10.1029/ 2002GL016446.

Broecker, W. S. (1994), Massive iceberg discharges as triggers for global climate change, Nature, 372, 421-424.

Chen, F. H., J. Bloemendal, J. M. Wang, J. J. Li, and F. Oldfield (1997), High-resolution multi-proxy climate records from Chinese loess: Evidence for rapid climatic changes over the last 75 kyr., Palaeogeogr. Palaeoclimatol. Palaeoecol., 130, 323-335.

Clemens, S. C., and R. J. Oglesby (1992), Interhemispheric moisture transport in the Indian Ocean summer monsoon: Data-model and modelmodel comparisons, Paleoceanography, 7(5), 633-643.

Dansgaard, W., J. W. C. White, and S. J. Johnsen (1989), The abrupt termination of the Younger Dryas climate event, Nature, 339, 532-534.

Flückiger, J., T. Blunier, B. Stauffer, J. Chappellaz, R. Spahni, K. Kawamura, J. Schwander, T. F. Stocker, and D. Dahl-Jensen (2004), $\mathrm{N}_{2} \mathrm{O}$ and $\mathrm{CH}_{4}$ variations during the last glacial epoch: Insight into global processes, Global Biogeochem. Cycles, 18, GB1020, doi:10.1029/2003GB002122.

Fuhrer, K., E. W. Wolff, and S. J. Johnsen (1999), Timescales for dust variability in the Greenland Ice Core Project (GRIP) ice core in the las 100,000 years, J. Geophys. Res., 104(D24), 31,043-31,052.

Gong, D.-Y., S.-W. Wang, and J.-H. Zhu (2001), East Asian winter monsoon and Arctic Oscillation, Geophys. Res. Lett., 28, 2073-2076.

Goswami, B. N., M. S. Madhusoodanan, C. P. Neema, and D. Sengupta (2006), A physical mechanism for North Atlantic SST influence on the Indian summer monsoon, Geophys. Res. Lett., 33, L02706, doi:10.1029/ 2005 GL024803.

Litt, T., A. Brauer, T. Goslar, J. Merkt, K. Balaga, H. Müller, M. RalskaJasiewiczowa, M. Stebich, and J. Negendank (2001), Correlation and synchronisation of Lateglacial continental sequences in northern central Europe based on annually laminated lacustrine sediments, Quat. Sci. Rev. $20,1233-1249$.

Liu, T., and Z. Ding (1998), Chinese loess and the paleomonsoon, Annu. Rev. Earth Planet. Sci., 26, 111-145.

Lu, H., X. Wang, H. Ma, H. Tan, J. Yandenberghe, X. Miao, Z. Li, Y. Sun, Z. An, and G. Cao (2004), The plateau monsoon variation during the past 130 kyr revealed by loess deposit at northeast Qinghai-Tibet (China), Global Planet. Change, 41, 207-214.

Mayewski, P. A., et al. (1994), Changes in atmospheric circulation and ocean ice cover over the North Atlantic during the last 41,000 years, Science, 263, 1747-1751.

Meeker, L., and P. Mayewski (2002), A 1400-year high-resolution record of atmospheric circulation over the North Atlantic and Asia, Holocene, $12(3), 257-266$

Nakagawa, T., H. Kitagawa, Y. Yasuda, P. E. Tarasov, K. Nishida, K. Gotanda, Y. Sawai, and Y. R. C. P. members (2003), Asynchronous climate changes in the North Atlantic and Japan during the last termination, Science, 299, 688-691.
North Greenland Ice Core Project (NGRIP) members (2004), Highresolution record of Northern Hemisphere climate extending into the last interglacial period, Nature, 431, 147-151.

Porter, S. C. (2001), Chinese loess record of monsoon climate during the last glacial-interglacial cycle, Earth Sci. Rev., 54, 115-128.

Porter, S. C., and Z. An (1995), Correlation between climate events in the North Atlantic and China during the last glaciation, Nature, 375, 305308 .

Rasmussen, S. O., et al. (2006), A new Greenland ice core chronology for the last glacial termination, J. Geophys. Res., 111, D06102, doi:10.1029/ 2005JD006079.

Ruth, U., D. Wagenbach, M. Bigler, J. P. Steffensen, R. Röthlisberger, and H. Miller (2002), High resolution dust profiles at NGRIP: Case studies of the calcium-dust relationship, Ann. Glaciol., 35, 209-216.

Ruth, U., D. Wagenbach, J. P. Steffensen, and M. Bigler (2003), Continuous record of microparticle concentration and size distribution in the centra Greenland NGRIP ice core during the last glacial period, J. Geophys. Res., 108(D3), 4098, doi:10.1029/2002JD002376.

Steffensen, J. P. (1997), The size distribution of microparticles from selected segments of the Greenland Ice Core Project ice core representing different climatic periods, J. Geophys. Res., 102(C12), 26,755-26,763.

Sun, J., M. Zhang, and T. Liu (2001), Spatial and temporal characteristics of dust storms in China and its surrounding regions, 1960-1999: Relations to source area and climate, J. Geophys. Res., 106(D10), 10,325-10,333.

Svensson, A., P. E. Biscaye, and F. E. Grousset (2000), Characterization of late glacial continental dust in the Greenland Ice Core Project ice core, J. Geophys. Res., 105(D24), 4637-4656.

Wang, P., S. C. Clemens, L. Beaufort, P. Branconnot, G. M. Ganssen, Z. Jian, P. Kershaw, and M. Sarnthein (2005), Evolution and variability of the Asian monsoon system: State of the art and outstanding issues, Quat. Sci. Rev., 24, 595-629.

Wang, Y. J., H. Cheng, R. L. Edwards, Z. S. An, J. Y. Wu, C.-C. Shen, and J. A. D'Orale (2001), A high-resolution absolute-dated late Pleistocene monsoon record from Hulu Cave, China, Science, 294, 2345-2348.

Xiao, J., Z. An, T. Liu, Y. Inouchi, H. Kumai, S. Yoshikawa, and Y. Kondo (1999), East Asian monsoon variation during the last 130,000 years: Evidence from the Loess Plateau of central China and Lake Biwa of Japan, Quat. Sci. Rev., 18, 147-157.

M. Bigler, S. J. Johnsen, M.-L. Siggaard-Andersen, and J. P. Steffensen, Ice and Climate Research, Niels Bohr Institute, University of Copenhagen, Juliane Maries Vej 30, Copenhagen DK-2100, Denmark.

K. Goto-Azuma, National Institute of Polar Research, 1-9-10 Kaga, Itabashi-ku, Tokyo 173-8515, Japan.

M. E. Hansson, Department of Physical Geography and Quaternary Geology, Stockholm University, Stockholm SE-10691, Sweden.

S. Kipfstuhl and U. Ruth, Alfred-Wegener-Institut für Polar- und Meeresforschung, Columbusstrasse, Building D-3470, Bremerhaven D-27568, Germany. (uruth@awi-bremerhaven.de)

H. Lu, School of Geographical and Oceanographical Sciences, Nanjing University, Nanjing 210093, China.

R. Röthlisberger, British Antarctic Survey, Natural Environment Research Council, High Cross, Madingley Road, Cambridge CB3 0ET, UK. 